\title{
EFFECT OF THE IMPROVED PROTEIN-MINERAL ADDITIVE ON STRUCTURAL-MECHANICAL CHARACTERISTICS OF MINCED MEAT
}

\author{
Kateryna Leshchenko ${ }^{T}$ \\ Maksym Serik ${ }^{1}$ \\ Yevgen Pyvovarov \\ Andrii Zahorulko ${ }^{2} \bowtie$ \\ zagorulkoAN@hduht.edu.ua \\ Aleksey Zagorulko ${ }^{2}$ \\ ${ }^{1}$ Department of Food Technology in the Restaurant Industry ${ }^{3}$ \\ ${ }^{2}$ Department of Equipment and Engineering of Processing and Food Production ${ }^{3}$ \\ ${ }^{3}$ State Biotechnological University \\ 44 Alchevskykh str., Kharkiv, Ukraine, 61002
}

Corresponding author

Abstract

The results of research on the effect of protein-mineral improved additive (PMIA) on the rheological parameters of minced meat, which can be used for manufacturing culinary products, including chopped semi-finished products of a high degree of readiness, are presented. It has been proven, that the additive can be used both as an ingredient, enriching calcium-digestible compounds and to improve a number of technological properties of minced meat, in particular after freezing, storage and thawing. The aim of the study was to determine the dependences of changes in the structural and mechanical characteristics of minced meat after the addition of PMIA and subsequent freezing to a temperature of $-16 \ldots-18{ }^{\circ} \mathrm{C}$ and storage for 20 days.

It has been found, that the addition of up to $7 \%$ of PMIA leads to a marked increase in the conditionally instantaneous modulus of elasticity and highly elastic modulus in 4.4 times for minced beef and 2.7 and 4.4 times for chicken, respectively. It has been established, that the best stabilization of these indicators after freezing occurs at the content of PMIA at the level of $2 \ldots 5 \%$. Studies of plastic viscosity and adhesion have shown that the use of up to $7 \%$ of PMIA leads to an increase of $11 \ldots 20 \%$ and $26 \ldots 64 \%$, respectively. After freezing, the plastic viscosity and adhesion of minced beef in the control decreased by 22.0 and $52 \%$, respectively, minced chicken - by 23.4 and $40.9 \%$. In the samples with a content of $7 \%$ of PMIA, the decrease in plastic viscosity and adhesion is 7.2 and $4.4 \%$ in minced beef and in chicken -5.9 and $3.1 \%$ respectively.

It has been proven, that the use of PMIA in the amount of up to $7 \%$ in the technology of minced meat production minimizes the negative destructive effect of low temperatures on the structural and mechanical characteristics of the finished product. Thus, it is expedient to use up to $7.0 \%$ of the improved protein-mineral additive in the composition of minced meat to enrich the finished product with digestible calcium compounds and improve their structural and mechanical characteristics, in particular after freezing and storage.

Keywords: improved protein-mineral additive; calcium compounds; minced meat; cut meat semi-finished products; structural and mechanical properties.

DOI: 10.21303/2504-5695.2021.002089

\section{Introduction}

The food industry, in particular the production of meat products, is constantly evolving through the development of new and improvement of existing product technologies with improved consumer characteristics. To adjust the composition of meat products and semi-fin- 
ished products, the introduction of ingredients that enrich products with deficient mineral nutrients has become widespread, namely: ones of plant and animal origin, vitamin and mineral additives, algae [1-4]; various ways to extend the shelf life (freezing, use of ingredients with preservative properties, etc.) [5], enrichment with calcium compounds [6-11], replacement of animal fat with components of plant origin [12] and the addition of non-traditional raw materials $[13,14]$. Structural and mechanical properties significantly affect the course of thermal, mechanical processes and storage (at low temperatures), which plays a role in the behavior of meat products in various technological processes, structure, digestibility of the product, as well as their organoleptic characteristics. The importance of regulating the structural and mechanical properties has made the use of various ingredients $[15,16]$ widespread to regulate these issues: shape retention in the formation of products and heat treatment; textural perception of the product; indicator of parameters in the structure and the state of moisture during storage.

The use of these methods allows to increase consumer characteristics, as well as biological and nutritional values of finished products, which makes it possible to create products with an adjustable nutrient composition. This is an important area, as recently there is a deficiency of calcium, vitamins and various minerals in the human body during its life

With this in mind, the aim of the work is to study the effect of the introduction of the improved protein-mineral additive, which is used as an enriching and technological ingredient, on the structural and mechanical characteristics of minced beef and chicken. As an enriching component, it is proposed to use the improved protein-mineral additive [17]. Its chemical composition (PMIA) is a partially thermally hydrolyzed collagen proteins, which are a matrix for the formation of chelate complexes with calcium and magnesium. The calcium compounds, contained in the additive, are in two states - calcium citrate and chelate complexes, which allow the accumulation of calcium in the tissues due to the high metabolic activity of chelate complexes and maintain the level of calcium in the consumer's blood due to citrates. The improved form of the additive also contains chondroitin sulfates, which have pronounced complex-forming properties and are an important metabolic factor that ensures the absorption of calcium compounds and its accumulation in human tissues [17].

The study of qualitative characteristics of products with an adjustable nutrient composition is an important aspect of the development of these semi-finished products. This is because the addition of new ingredients to the recipe can affect the standard quality, nutritional and biological value of the product in different ways. At the same time, one of the main ways to store semi-finished meat products is freezing, which often leads to a significant deterioration in a number of characteristics of meat systems. This is due to crystallization of moisture and destructive transformations of a number of key nutrients, including proteins. One of the most unstable characteristics after freezing is structural and mechanical properties. Their stabilization is an important task along with increasing the nutritional and biological value of products.

Thus, in order to determine the influence of PMIA on structural and mechanical properties of minced meat, in particular chicken and beef, it is necessary to solve the following tasks:

- to investigate the dynamics of the conditionally instantaneous modulus of elasticity, highly elastic modulus, plastic viscosity and adhesion of minced meat samples depending on the amount of the introduced additive, as one of the key characteristics that form their rheological characteristics;

- to investigate the dependences of changes in the above characteristics after freezing, storage and thawing of cut meat systems to assess the cryostabilizing effect of PMIA.

\section{Materials and methods}

The object of the study is minced meat of beef and chicken (based on fillets) with PMIA [17]. The additive was introduced to the minced meat systems in the amount of $1.0 . .7 .0 \%$ of the weight of meat. Samples of the minced meat systems, made without the additive, served as controls. The additive contains protein-mineral calcium and magnesium. PMIA 
also contains chondroitin sulfates up to $20 \%$, which in addition to high biological activity, which is directly involved in the absorption of calcium, perform a number of technological functions (stabilization of dispersed systems, moisture binding, etc.), which determine the feasibility and prospects of using this additive in the composition of meat semi-finished products, in particular a high degree of readiness $[17,18]$. The total chemical composition in the dry state of PMIA is given in Table 1 [19].

Table 1

The chemical composition of the improved protein-mineral additive

\begin{tabular}{cc}
\hline $\begin{array}{c}\text { Parameter } \\
\text { name }\end{array}$ & $\begin{array}{c}\text { Improved } \\
\text { protein-mineral additive }\end{array}$ \\
\hline Mass share of moisture, \% & $6.2 \pm 0.2$ \\
Mass share of protein, \% & $60.2 \pm 2.5$ \\
Mass share of fat, \% & $6.5 \pm 0.3$ \\
Mass share of chondroitin sulfate, \% & $19 \pm 1.0$ \\
Mass share of ash, \% & $8.1 \pm 0.3$ \\
Mass share of calcium, \% & $6.7 \pm 0.0 .35$ \\
Mass share of magnesium, \% & $0.31 \pm 0.02$
\end{tabular}

In the total amount of calcium in the additive, about $60 \ldots 65 \%$ is represented by its protein-bound form, which has a high metabolic activity. $35 \ldots 40 \%$ of calcium is in the form of citrate, which exhibits characteristic antioxidant and preservative properties. The additive is presented in a homogeneous powder state, has a pale cream color and neutral taste and aromatic characteristics.

The following structural and mechanical properties were studied: conditionally instantaneous modulus of elasticity, highly elastic modulus, plastic viscosity. The study was performed on Tolstoy's elastoplastometer [20] by studying the shear deformation of a sample, located between plates. Due to the applied deformation force, the deformation curve was calculated, which allowed to calculate the above characteristics.

The study of minced meat was carried out in the freshly prepared state, and after freezing to a temperature of $-18{ }^{\circ} \mathrm{C}$, storage at a temperature of $\left(-16 \ldots-18{ }^{\circ} \mathrm{C}\right)$ for 20 days, followed by thawing to a temperature of $4 \ldots 6^{\circ} \mathrm{C}$.

Adhesion was determined by measuring the force, required to separate the AISI 304 food grade stainless steel plate from the minced meat sample with the specified geometric parameters [20].

The samples were made according to the traditional recipe and technology with appropriate preparation of the additive.

\section{Research results and their discussion}

In accordance with the purpose of our work, we conducted a research to determine the structural and mechanical parameters of minced meat: conditionally instantaneous modulus of elasticity, highly elastic modulus, plastic viscosity, adhesion. These characteristics are key indicators that affect the form stability of products, ease of molding, including on automated equipment, changes in moisture when varying the recipe or process parameters, the nature and density of interaction of the components of minced meat and more. If minced meat is frozen, the key point is to preserve the rheological characteristics of meat systems after thawing, which will indicate the stabilization of moisture and less profound destructive processes, associated with the destruction of the product. This is important to ensure the stable characteristics of the product, regardless of how it is stored. 
The results of the studies of minced beef and chicken with the content of PMIA, freshly made and after freezing $\left(-16 \ldots-18{ }^{\circ} \mathrm{C}\right)$, storage for 20 days and subsequent thawing are shown in Fig. 1-4.

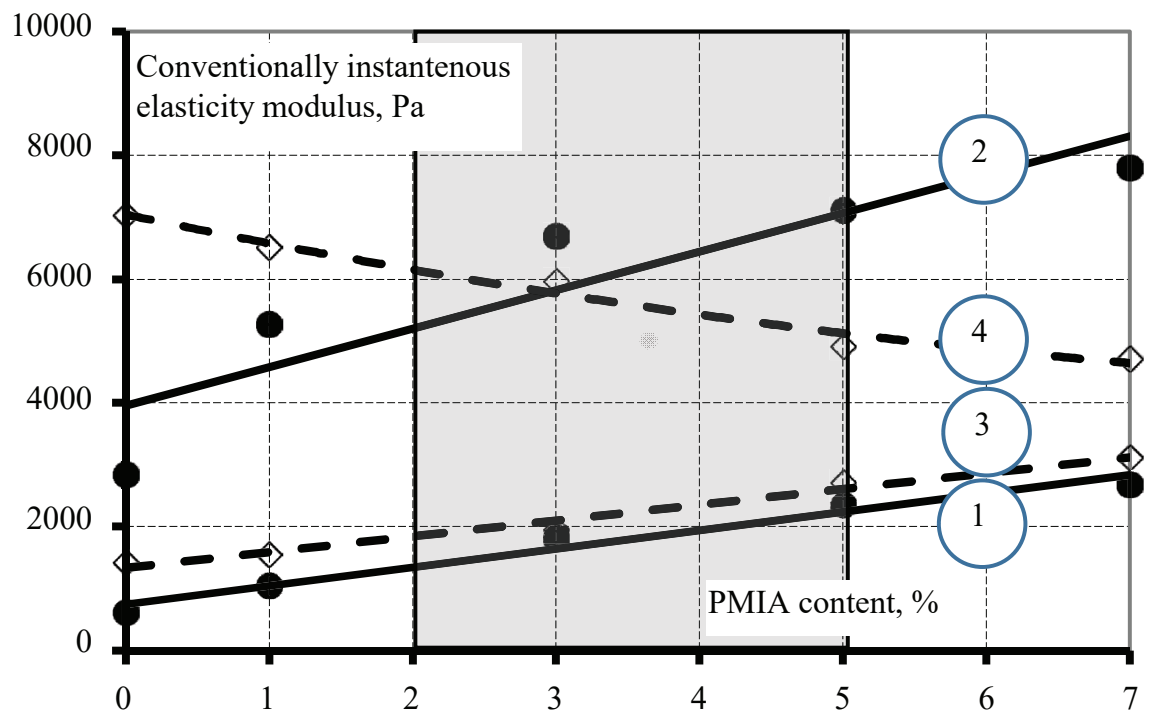

Fig. 1. Conditionally instantaneous elasticity modulus of minced meat: beef: 1 - before freezing; 3 - after freezing and thawing; chicken: 2 - before freezing; 4 - after freezing and thawing

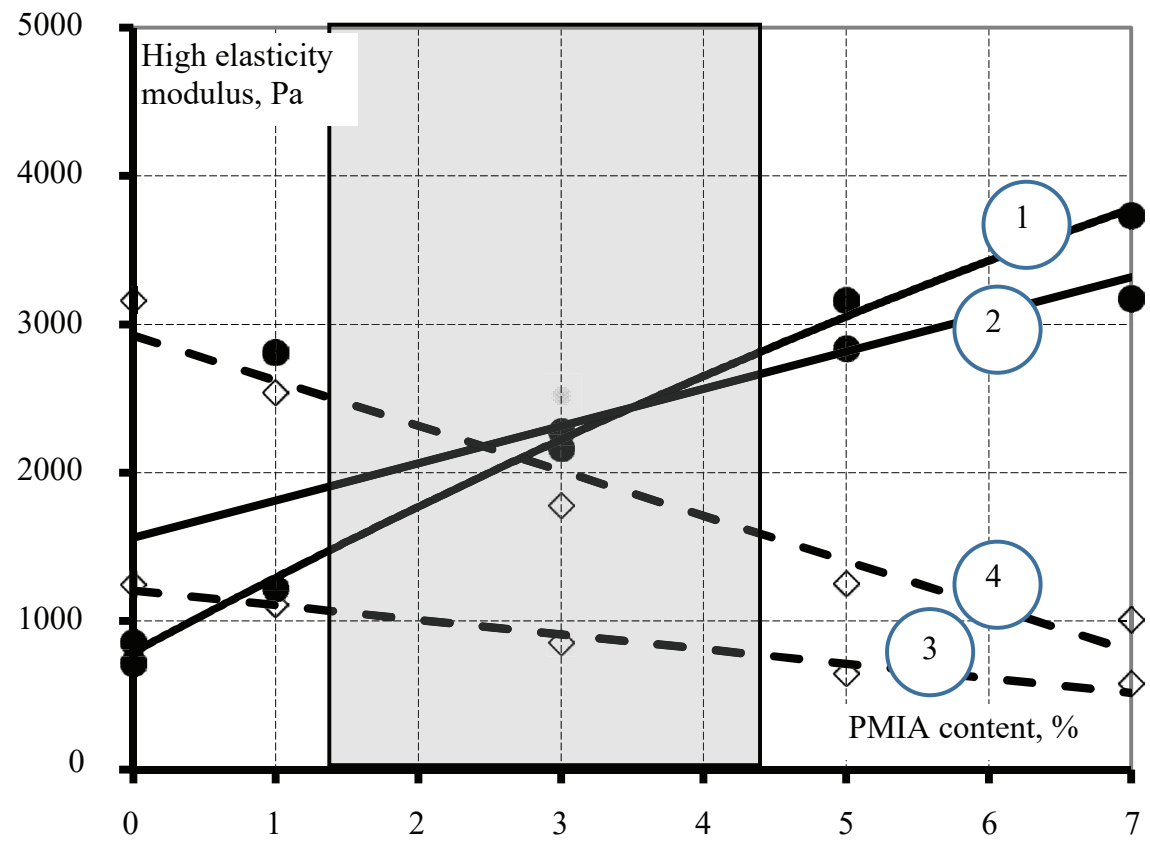

Fig. 2. High elasticity modulus of minced meat: beef: 1 - before freezing; 3 -after freezing and thawing; chicken: 2 - before freezing; 4 - after freezing and thawing

The analysis of the results, presented in Fig. 1-4, allows us to talk about the following trends. The addition of up to $7 \%$ of PMIA leads to a marked increase in the conditionally instantaneous modulus of elasticity and highly elastic modulus in 4.4 times for minced beef and 2.7 and 4.4 times for chicken, respectively. This is probably due to the fact that the components of the additive (chondroitin sulfates, partially hydrolyzed collagen proteins) in the hydrated 
state increase the viscosity of the dispersed medium and help to seal the bonds between the components of mince meat. As a result of applying a load to such meat systems, they resist and restore their original structure well after its removal. As a result of freezing, storage and thawing of minced chicken, there is an inversion of trends. Beef minced meat has a tendency to increase the conditionally instantaneous modulus of elasticity, but there is an inversion of the tendency to change the highly elastic modulus, due to the higher content of the connective tissue in minced beef compared to minced chicken. It is known, that connective tissue proteins are more resistant to the negative effects of low temperatures. The most labile are sarcoplasmic proteins, the share of which in minced chicken is higher than in beef. These trends are due to the destructive effects of freezing. Probably, the elasticity of minced chicken is lost due to the partial destruction by frozen moisture. The most pronounced tendency is observed in the control and when the content of the additive is more than $5 \%$. The smallest changes in the characteristics before and after freezing are observed when the content of the additive at the level of $2 \ldots .5 \%$.

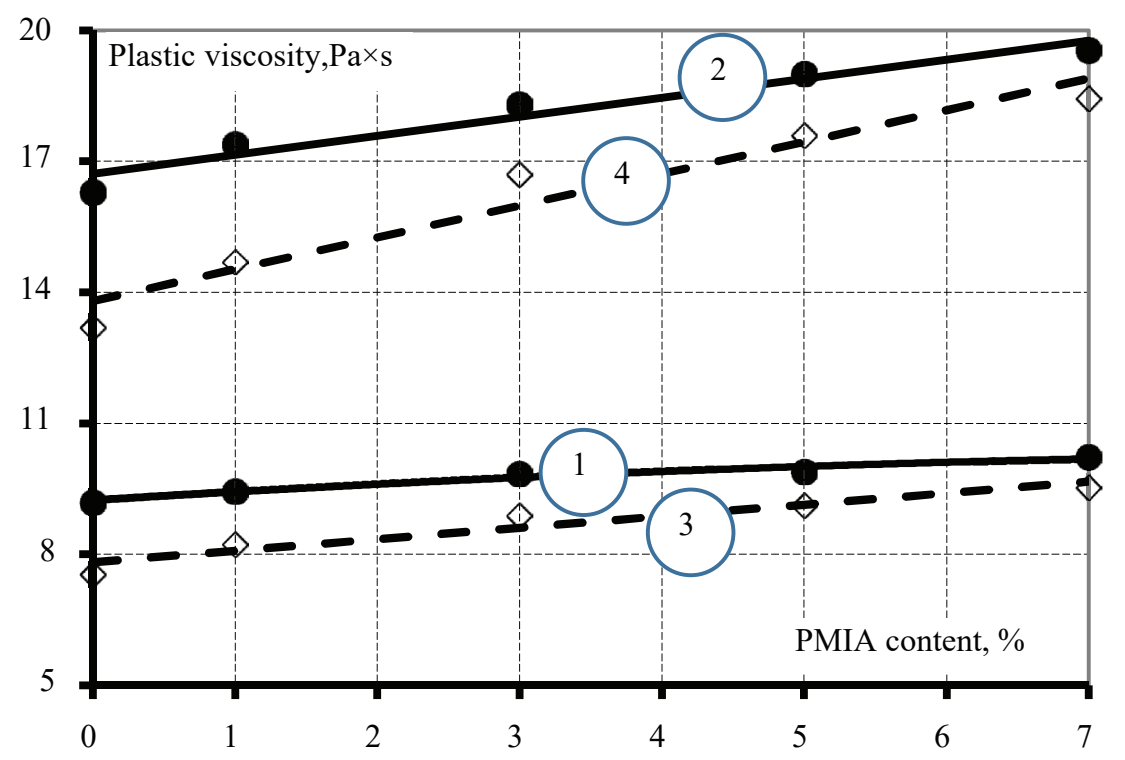

Fig. 3. Plastic viscosity of minced meat: beef: 1 - before freezing; 3 - after freezing and thawing; chicken: 2 - before freezing; 4 - after freezing and thawing

The studies of plastic viscosity and adhesion have shown that the use of up to $7 \%$ of PMIA leads to an increase of $11 . .20 \%$ and $26 \ldots 64 \%$, respectively. After freezing, the plastic viscosity and adhesion of minced beef in the control decreased by 22.0 and $52 \%$, respectively, chicken mince - by 23.4 and $40.9 \%$. In samples with a content of $7 \%$ of PMIA, the reduction in plastic viscosity and adhesion are respectively in minced beef 7.2 and $4.4 \%$, in chicken -5.9 and $3.1 \%$.

Probably, the above changes are due to the fact that the use of PMIA provides stabilization of moisture and inhibition of water crystal growth. The pronounced cryoprotective effect of PMIA determines preservation of the structure of the minced meat during freezing. This prevents the denaturation transformation of labile sarcoplasmic protein fractions and allows to significantly preserve the structural and mechanical characteristics of the cut meat systems. Preservation of the structural and mechanical characteristics of the cut meat systems after freezing will provide stability of organoleptic indicators of quality of the finished culinary products, made with its use.

The possibility of the negative impact of high mineralization on the functional and technological characteristics of the minced meat systems, in particular due to the negative impact 
on sarcoplasmic and myofibrillar protein fractions, is not affected by the following factors. First, at least $60 \%$ of the calcium, ingested with PMIA, is in the protein-bound chelate state. Secondly, the mineral calcium, which is contained in citrate, has a low degree of dissociation. The above circumstances are due to the lack of intensive accumulation of calcium ions in the product, and their small amounts are not able to significantly adversely affect the behavior of the cut meat systems. The potential negative effect of $\mathrm{Ca}^{2+}$ ions is fully compensated and not eliminated by the moisture-retaining and structuring properties of partially hydrolyzed collagen proteins and chondroitin sulfates. Such solutions make it possible to realize the enrichment of meat foods with deficient mineral compounds, in particular calcium, without deteriorating their technological characteristics.

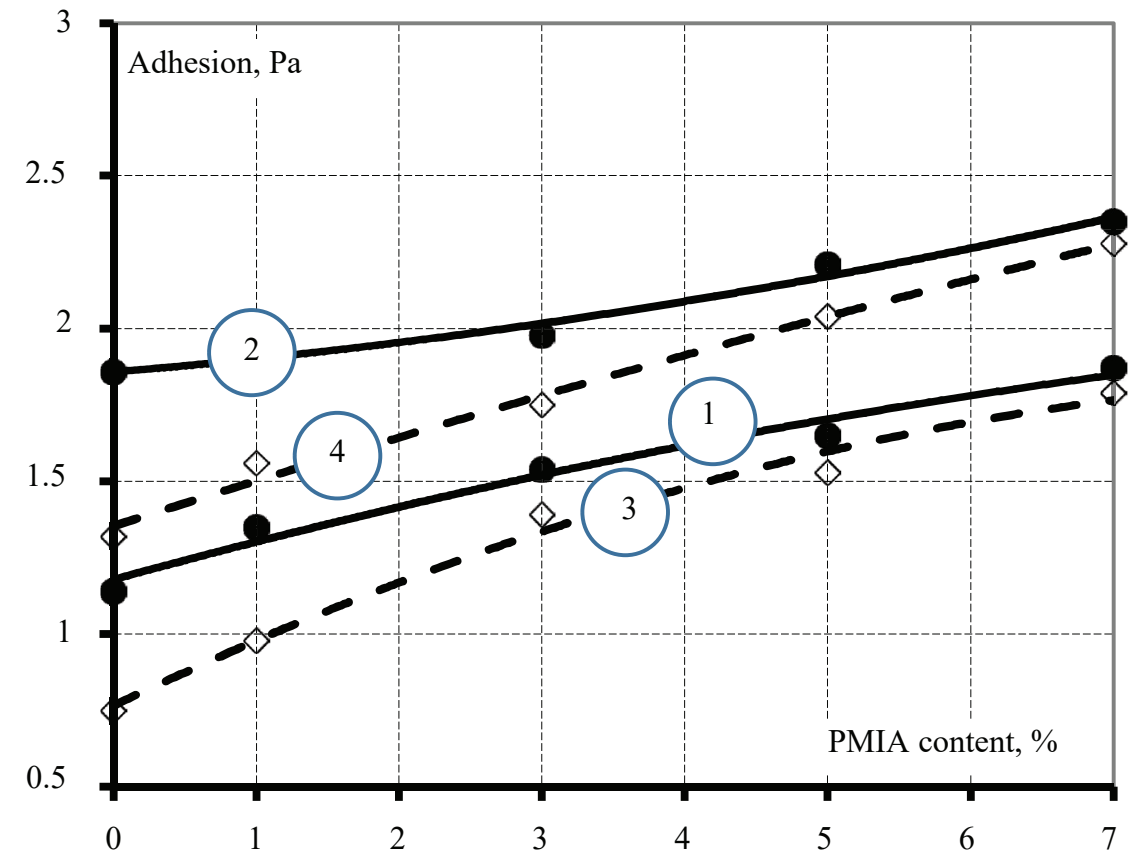

Fig. 4. Adhesion of minced meat to AISI 304 stainless steel: beef: 1 - before freezing; 3 - after freezing and thawing; chicken: 2 - before freezing; 4 - after freezing and thawing

The above indicates certain competitive advantages of innovative minced meat products with the use of PMIA to ensure the stability of its consumer characteristics.

\section{Conclusions}

Based on the obtained results, it can be concluded, that the use of PMIA in the technology of minced meat for culinary products allows:

- to increase the conditionally instantaneous modulus of elasticity and highly elastic modulus of minced beef and minced chicken, which has a positive effect on the sensory texture perception of the product by the consumer;

- to ensure maximum preservation of the elasticity modulus and highly elastic modulus after freezing, storage and thawing when using PMIA in the amount of $2 \ldots 5 \%$;

- to increase the plastic viscosity and adhesion of minced meat, which improves the ability to mold products and retain their desired shape;

- to ensure better stability of the plastic viscosity and adhesion characteristics of the cut meat systems after freezing, storage and thawing when using PMIA in the amount of up to $7 \%$.

The obtained results allow to state that the use of PMIA in the technology of minced meat products allows to improve a number of structural and mechanical characteristics of 
minced meat, to favor the improvement of their structure. The cryoprotective effect of PMIA on minced meat has been proved, which is justified by the ability to preserve their structural and mechanical characteristics after freezing and thawing better than in minced meat, made by the traditional technology.

The obtained results will allow to introduce the use of PMIA in the composition of meat semi-finished products and to ensure the stability of their structural and mechanical parameters, and hence the textural perception of the product, after freezing and storage. The prospect of further research is the organization of histological studies of the microstructure of minced meat, in particular after cryogenic exposure, in order to determine the nature of the interaction between its individual components.

\section{References}

[1] Kovtun, A. V., Koval, O. A., Halinska, O. S. (2014). Improvement of the technology of meat of products from the nucleus semechky Sunflowers. Suchasni napriamky tekhnolohii ta mekhanizatsii protsesiv pererobnykh i kharchovykh vyrobnytstv. Visnyk Kharkivskoho natsionalnoho tekhnichnoho universytetu silskoho hospodarstva imeni Petra Vasylenka, 152, 334-340. Available at: http://dspace.nuft.edu.ua/jspui/handle/123456789/20372

[2] Mehta, N., Ahlawat, S. S., Sharma, D. P., Dabur, R. S. (2013). Novel trends in development of dietary fiber rich meat products a critical review. Journal of Food Science and Technology, 52 (2), 633-647. doi: https://doi.org/10.1007/s13197-013-1010-2

[3] Rajkumar, V., Verma, A. K., Patra, G., Pradhan, S., Biswas, S., Chauhan, P., Das, A. K. (2015). Quality and Acceptability of Meat Nuggets with Fresh Aloe vera Gel. Asian-Australasian Journal of Animal Sciences, 29 (5), 702-708. doi: http://doi.org/ 10.5713/ajas.15.0454

[4] Turgut, S. S., Işıkçı, F., Soyer, A. (2017). Antioxidant activity of pomegranate peel extract on lipid and protein oxidation in beef meatballs during frozen storage. Meat Science, 129, 111-119. doi: http://doi.org/10.1016/j.meatsci.2017.02.019

[5] Pasichnyi, V. M., Heredchuk, A. M., Moroz, O. O., Yastreba, Yu. A. (2015). Investigation of the factors of shelf-lifeprolongation for meat and meat-containing products. Naukovi pratsi Natsionalnoho universytetu kharchovykh tekhnolohii, 21 (4), $224-230$. Available at: http://dspace.nuft.edu.ua/jspui/handle/123456789/28092

[6] Cáceres, E., García, M. L., Selgas, M. D. (2006). Design of a new cooked meat sausage enriched with calcium. Meat Science, 73 (2), 368-377. doi: http://doi.org/10.1016/j.meatsci.2005.12.016

[7] Soto, A. M., Morales, P., Haza, A. I., García, M. L., Selgas, M. D. (2014). Bioavailability of calcium from enriched meat products using Caco-2 cells. Food Research International, 55, 263-270. doi: http://doi.org/10.1016/j.foodres.2013.10.038

[8] Olmedilla-Alonso, B., Jiménez-Colmenero, F., Sánchez-Muniz, F. J. (2013). Development and assessment of healthy properties of meat and meat products designed as functional foods. Meat Science, 95 (4), 919-930. doi: http://doi.org/10.1016/ j.meatsci.2013.03.030

[9] Cherevko, O. I., Holovko, M. P., Polevych, V. V. Chuiko, L. O. Serik, M. L. Holovko, T. M. (2010). Vykorystannia produktiv pererobky kharchovoi kistky u tekhnolohii produktiv spetsialnoho pryznachennia. Kharkiv: KhDUKhT, 201. Available at: http://elib.hduht.edu.ua/jspui/handle/123456789/2439

[10] Holovko, M. P., Serik, M. L., Holovko, T. M., Polupan, V. V. (2013). Tekhnolohiia miasnykh posichenykh vyrobiv iz vykorystanniam napivfabrykatu bilkovo-mineralnoho. Naukovi pratsi Odeskoi natsionalnoi akademii kharchovykh tekhnolohii, 2 (44), 189-193. Available at: http://nbuv.gov.ua/UJRN/Np_2013_44\%282\%29_46

[11] Filippov, M. V. (2013). Suchasnyi stan ta problemy funktsionuvannia rynku miasnoi produktsii v Ukraini. Visnyk ONU im. I. I. Mechnikova, 18 (2/1), 183-187. Available at: http://nbuv.gov.ua/UJRN/Vonu_econ_2013_18_2\%281\%29_43

[12] Nieto, G., Martínez, L., Castillo, J., Ros, G. (2017). Hydroxytyrosol extracts, olive oil and walnuts as functional components in chicken sausages. Journal of the Science of Food and Agriculture, 97 (11), 3761-3771. doi: http://doi.org/10.1002/jsfa.8240

[13] Azarova, N. H., Shlapak, H. V., Chukharev, V. A. (2018). Miaso indykiv u diabetychnomu kharchuvanni. Tekhnolohii kharchovykh produktiv i kombikormiv. Odesa, 54-55. Available at: https://card-file.onaft.edu.ua/handle/123456789/8261

[14] Paska, M. Z., Masliichuk, O. B. (2016). Microbiological and consumer characteristics of semi finished meat splits adding lyupyn flour and elecampane. Naukovyi visnyk LNUVMBT imeni S. Z. Gzhytskoho, 18 (4 (72)), 120-123. Available at: http:// repository.ldufk.edu.ua/handle/34606048/22295

[15] Strashynskyi, I. M., Pasichnyi, V. M., Fursik, O. P. (2016). Stabilization of parameters of minced meat for sausages using blend that contains protein. Naukovi pratsi Natsionalnoho universytetu kharchovykh tekhnolohii, 22 (1), 210-218. Available at: http://nbuv.gov.ua/UJRN/Npnukht_2016_22_1_26 
[16] Pasichnyi, V. M., Yastreba, Yu. A. (2013). Doslidzhennia strukturno-mekhanichnykh vlastyvostei heliv alhinativ dlia vyrobnytstva miasnykh ta miasomistkykh produktiv. Naukovyi visnyk Lvivskoho natsionalnoho universytetu veterynarnoi medytsyny ta biotekhnolohii im. Gzhytskoho, 15 (1 (3)), 125-129. Available at: http://nbuv.gov.ua/UJRN/nvlnu_2013_15_1(3)__23

[17] Cherevko, O. I., Mykhailov, V. M., Holovko, M. P., Holovko, T. M., Serik, M. L., Polupan, V. V., Bakirov, M. P. (2013). Naukovi osnovy tekhnolohii mineralizovanykh produktiv kharchuvannia. Ch. 3. Tekhnolohiia zbahachuvalnykh bilkovo-mineralnykh dobavok ta produktiv kharchuvannia ozdorovchoho pryznachennia z yikh vykorystanniam. Kharkiv: KhDUKhT, 165. Available at: https://elib.hduht.edu.ua/handle/123456789/2453

[18] Serik, M. L., Shurduk, I. V. (2018). Udoskonalennia tekhnolohii ta yakosti miasnykh emulsiinykh vyrobiv, zbahachenykh kaltsiiem. Kharkiv: KhDUKhT, 130. Available at: https://elib.hduht.edu.ua/bitstream/123456789/2821/1/2018_\%D0\%BF\%D0\%BE\%D0\%B7.\%20182.pdf

[19] Leshchenko, K. H., Serik, M. L., Pyvovarov, Ye. P. (2021). Proteinand mineral additive effect on some characteristics of meat minced systems. Prohresyvni tekhnika ta tekhnolohii kharchovykh vyrobnytstv restorannoho hospodarstva i torhivli, 1 (33), 19-31. Available at: http://elib.hduht.edu.ua/jspui/handle/123456789/6560

[20] Antipova, L. V., Glotova, I. A., Rogov, I. A. (2004). Metody issledovaniia miasa i miasnykh produktov. Moscow: Kolos, 571. Available at: http://padaread.com/?book=42066\&pg=1

How to cite: Leshchenko, K., Serik, M., Pyvovarov, Y., Zahorulko, A., Zagorulko, A. (2021). Effect of the improved protein-mineral additive on structural-mechanical characteristics of minced meat. EUREKA: Life Sciences, 5, 46-53. doi: https://doi.org/ 10.21303/2504-5695.2021.002089 